\title{
Intravitreal and posterior subtenon triamcinolone acetonide for severe acute posterior multifocal placoid pigment epitheliopathy
}

\section{Triancinolona intravítrea e sub-tenoniana para epiteliopatia pigmentar placóide multifocal posterior aguda grave}

\author{
Raul N. G. Vianna', Vinícius Vanzan', Remo Turchetti², Miguel N. Burnier JR. ${ }^{3}$ \\ 1. Department of Ophthalmology, Universidade Federal Fluminense, Niterói, RJ, Brazil. \\ 2. Instituto Brasileiro de Oftalmologia, Rio de Janeiro, RJ, Brazil. \\ 3. Department of Ophthalmology, McGill University Health Centre, Montreal, Quebec, Canada.
}

\begin{abstract}
A 21-year-old man presented with visual acuity of $20 / 200$ in both eyes. The fundus picture, fluorescein angiography, and optical coherence tomography revealed severe bilateral acute posterior multifocal placoid pigment epitheliopathy and serous macular detachments. We treated the patient with triamcinolone acetonide, an intravitreal injection $(4 \mathrm{mg} / 0.1 \mathrm{~mL})$ in one eye and a posterior subtenon injection $(40 \mathrm{mg} / 1 \mathrm{~mL})$ in the other eye. Within 2 weeks the visual acuity was $20 / 80$ in both eyes. At the 8-week follow-up visit his vision was 20/63 bilaterally. One year later the vision remained 20/63 in both eyes. In this patient, the triamcinolone acetonide injections, whether administered intravitreally or via the posterior subtenon route, achieved similar anatomic and functional recovery results.
\end{abstract}

Keywords: Pigment epithelium of eye; Choroid diseases; Chorioretinopathy; Tomography, optical coherence; Triamcinolone acetonide

RESUMO | Um homem de 21 anos apresentou acuidade visual de 20/200 em ambos os olhos. O quadro de fundo de olho, angiofluoresceinografia e a tomografia de coerência óptica revelaram epiteliopatia pigmentar placóide multifocal posterior aguda e descolamento macular seroso. Tratamos o paciente com triancinolona acetonida, uma injeção intravítrea $(4 \mathrm{mg} / 0,1 \mathrm{ml}) \mathrm{em}$ um olho e uma injeção subtenoniana posterior $(40 \mathrm{mg} / 1 \mathrm{ml})$ no outro olho. Após 2 semanas, a acuidade visual foi de 20/80 em ambos os olhos. Na visita de acompanhamento de 8 semanas,

Submitted for publication: July 24, 2018

Accepted for publication: November 24, 2018

Funding: No specific financial support was available for this study.

Disclosure of potential conflicts of interest: None of the authors have any potential conflicts of interest to disclose.

Corresponding author: Raul N.G. Vianna.

Rua Gal. Mariante 88/802 - Rio de Janeiro, RJ - 22221-100 - Brazil

E-mail: rngvianna@yahoo.com.br sua visão foi de 20/63 bilateralmente. Um ano depois, a visão permaneceu 20/63 em ambos os olhos. Neste paciente, as injeções de triancinolona, administradas por via intravítrea ou por via subtenoniana posterior, obtiveram resultados semelhantes na recuperação anatômica e funcional.

Descritores: Epitélio pigmentado ocular; Doenças da coroide; Coriorretinopatia; Tomografia de coerência óptica; Triancinolona acetonida

\section{INTRODUCTION}

Acute posterior multifocal placoid pigment epitheliopathy (APMPPE), described by Gass in 1968, typically affects both eyes of young healthy adults aged 20-50 years ${ }^{(1)}$. The fundus picture is characterized by multiple, circumscribed, yellow-white lesions situated primarily in the posterior pole at the level of the retinal pigment epithelium (RPE) ${ }^{(1)}$. The cause of APMPPE remains speculative. The relative frequency of upper respiratory tract infections preceding the symptoms points to a possible viral etiology ${ }^{(1,2)}$.

APMPPE appears to be self-limited, and no standard treatment for it exists ${ }^{(1,2)}$. However, two papers showing that half of the affected eyes remain symptomatic and/or present incomplete recovery of visual function ${ }^{(3,4)}$, have led some ophthalmologists to prescribe systemic steroids, particularly in cases of macular involvement ${ }^{(5,6)}$.

Since oral steroids can cause systemic side-effects, a different effective route of administration would be preferable. In this report, we show the effects of intravitreal triamcinolone acetonide (IVTA) and posterior subtenon triamcinolone acetonide (PSTA) in a patient with bilateral APMPPE and macular serous detachments. 


\section{CASE REPORT}

A 21-year-old healthy man presented with bilateral acute loss of vision of 3 days of evolution. His best-corrected ETDRS visual acuity was 20/200 in both eyes. Slit-lamp examinations of the anterior segments were unremarkable. The intraocular tensions were within normal limits in both eyes. We saw multiple, circumscribed, yellow-gray lesions situated in the posterior pole at the level of the RPE in both fundi (Figure 1A and 1B). The optic disks and retinal vessels appeared normal. Fluorescein angiography showed hypofluorescence of the lesions in the early phases followed by late staining. Spectral domain-optic coherence tomography (SD-OCT) of both eyes revealed macular serous detachments, deep external lesions, and reflective material within the fluid (Figure 1C and 1D).

We diagnosed the patient as having severe bilateral APMPPE. Since APMPPE-like fundi can be seen in patients with syphilis, tuberculosis, or dengue fever, we ruled out infectious disorders by systemic investigations. No protocols for APMPPE treatment have been established; therefore, we discussed the pros and cons of treatment approaches with the patient. After obtaining informed consent from the patient and due to the bilateral macular serous detachments, we injected $4 \mathrm{mg} / 0.1 \mathrm{~mL}$ of triamcinolone acetonide intravitreally in the right eye and $40 \mathrm{mg} / 1 \mathrm{~mL}$ in the superotemporal subtenonian space of the left eye 5 days after the onset of symptoms. Within 2 weeks the visual acuities were 20/80 in each eye. At the 8-week follow-up visit the visual acuities were 20/63 bilaterally. Fundus pictures revealed RPE atrophy and pigment clumps throughout the posterior poles of both eyes (Figure 2A and 2B). Fluorescein angiography showed hyperfluorescence (window defects) in the affected areas as well as patches of hypofluorescence due to pigment clumps. SD-OCT revealed macular serous detachment resolutions in both eyes (Figure 2C and 2D). After 1 year the visions remained 20/63 in each eye. A diagnosis of relentless placoid epitheliopathy was initially proposed, but we excluded the disease due to the lack of the de novo lesions and recurrence. The intraocular tension remained inside normal limits during the entire follow-up period.

\section{DISCUSSION}

APMPPE is considered a self-limiting and benign disorder, but the long-term visual outcome after an acute episode does not appear as favorable as initially reported $^{(3,4)}$. The visual prognosis of the disease is strongly affected by the presence of initial foveal involvement. In

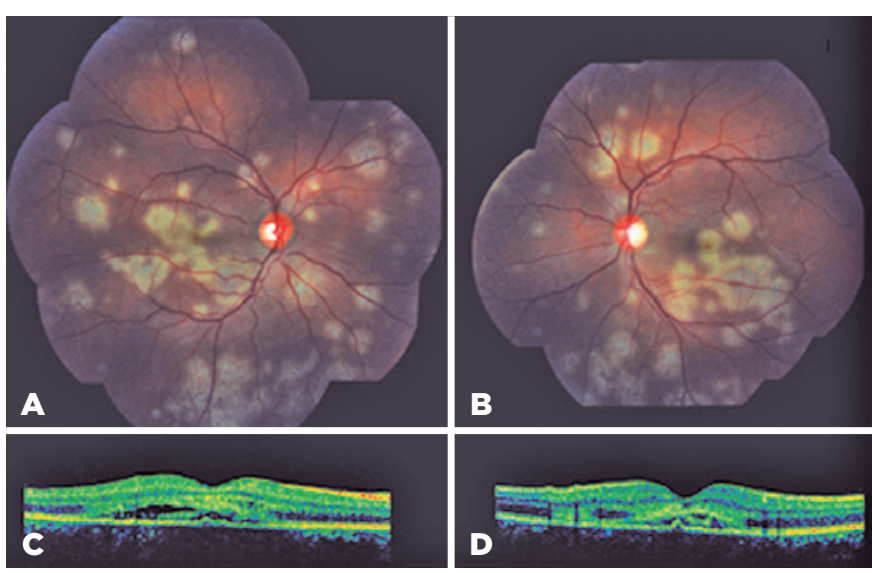

Figure 1. Multiple, circumscribed, yellow-gray lesions in the posterior pole at the level of the retinal pigment epithelium (RPE) in both fundi. The optic disks and retinal vessels appear normal ( $A$ and $B$ ). Spectral domain OCT of both eyes revealed macular serous detachment, deep APMPPE lesions, and a reflective material within the fluid ( $C$ and $D$ ).
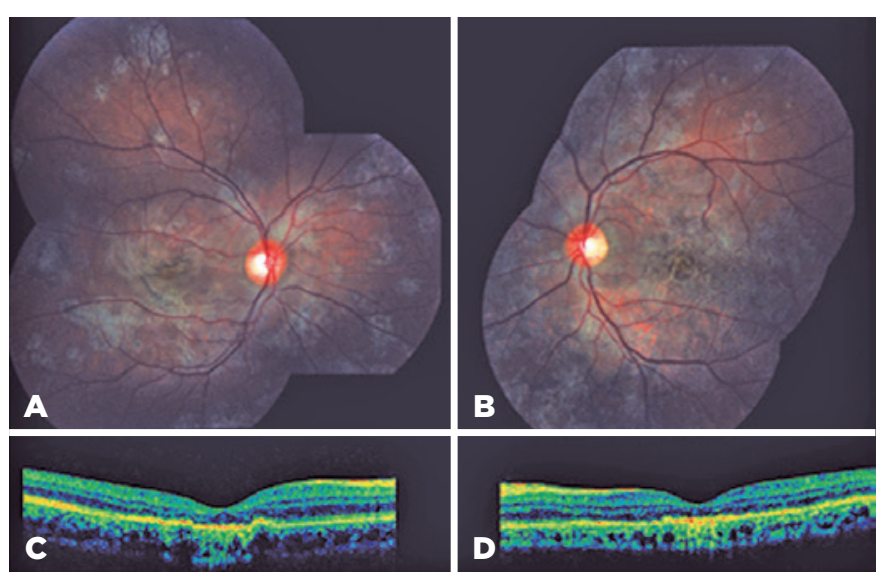

Figure 2. Eight weeks after diagnosis the fundus picture revealed retinal pigment epithelium (RPE) atrophy and pigment clumps throughout the posterior pole in both eyes ( $A$ and B). Spectral domain OCT showed the macular serous detachment had resolved in both eyes ( $C$ and $D)$.

fact, $88 \%$ of eyes without foveal involvement and $53 \%$ of eyes with foveal involvement get fully recovered ${ }^{(3,4,6)}$. Although foveal involvement does not necessarily prevent recovery, the eyes with poor visual recovery are usually those with initial foveal involvement and poor visual acuity at presentation ${ }^{(6)}$. Other characteristic features of the disease are the relatively rapid resolution of the fundus lesions and the delayed return of the vision function, which can take as long as six months in severe cases ${ }^{(1)}$.

The pathogenesis of APMPPE remains unknown, but it has been associated with choroidal inflammation. Some evidence suggests an obstruction at the level of the precapillary arterioles due to choroidal vasculitis ${ }^{(2)}$. The etiology of this entity also remains obscure, although an APMPPE-like picture can be seen associated with 
some infectious diseases like syphilis, tuberculosis or Dengue fever ${ }^{(7)}$.

Given the inflammatory process in the pathogenesis, the use of steroids for APMPPE makes sense. In fact, corticosteroids have been recommended for bilateral cases with severe visual loss, or for those involving the central nervous system ${ }^{(5)}$, but the data from the literature are not clear regarding the use of oral corticosteroids for APMPPE. More definitive data are required, and different administration routes need to be investigated.

The effects of IVTA and PSTA for various intraocular inflammatory disorders, including in those from the group of the so-called white dot syndromes, such as serpiginous choroiditis and multifocal choroiditis, and panuveitis have been reported ${ }^{(8)}$. On the other hand, we did not find any report on the results of the use of IVTA or PSTA in patients with severe APMPPE.

This paper showed that triamcinolone acetonide injection, whether administered intravitreally or via the posterior subtenon route, presented similar results achieving anatomic and functional recoveries. In our patient, the visual acuity did not improve beyond 20/63.

\section{REFERENCES}

1. Gass JD. Acute posterior multifocal placoid pigment epitheliopathy. Arch Ophthalmol. 1968;80(2):177-85.

2. Deutman AF, Oosterhuis JA, Boen-Tan TN, Aan de Kerk AL. Acute posterior multifocal placoid pigment epitheliopathy. Pigment epitheliopathy of choriocapillaritis? Br J Ophthalmol. 1972;56(12): 863-74.

3. Wolf MD, Alward WL, Folk JC. Long-term visual function in acute posterior multifocal placoid pigment epitheliopathy. Arch Ophthalmol. 1991;109(6):800-3.

4. Vianna R, van Egmond J, Priem H, Kestelyn P. Natural history and visual outcome in patients with APMPPE. Bull Soc Belge Ophtalmol. 1993;248:73-6.

5. O'Halloran HS, Berger JR, Lee WB, Robertson DM, Giovannini JA, Krohel GB, et al. Acute multifocal placoid pigment epitheliopathy and central nervous system involvement: nine new cases and a review of the literature. Ophthalmology. 2001;108(5):861-8.

6. Fiore T, laccheri B, Androudi S, Papadaki TG, Anzaar F, Brazitikos $\mathrm{P}$, et al. Acute posterior multifocal placoid pigment epitheliopathy: outcome and visual prognosis. Retina. 2009 Jul;29(7):994-1001.

7. Goldhardt R, Patel H, Davis JL. Acute posterior multifocal placoid pigment epitheliopathy following Dengue Fever: a new association for an old disease. Ocul Immunol Inflamm. 2016;24(6):610-4.

8. Vianna RN, Ozdal PC, Filho JP, Ventura MP, Saraiva VS, Deschênes J. Longterm follow-up of patients with multifocal choroiditis and panuveitis. Acta Ophthalmol Scand. 2004;82(6):748-53. 